\title{
Successful treatment of asymptomatic endometriosis: Does it benefit infertile women?
}

\author{
ERIC J THOMAS, IAN D COOKE
}

\begin{abstract}
The relation between asymptomatic endometriosis and infertility was investigated in a randomised double blind placebo controlled trial of the impact of treating the endometriosis with gestrinone. The 12 month cumulative conception rate in those patients treated with gestrinone was $25 \%(5 / 20)$ and in those given placebo $24 \%(4 / 17)$. These same patients were divided into those in whom no visible endometriosis was present at the second laparoscopy and those in whom residual disease was present and the 12 month cumulative conception rates were $25 \%(4 / 16)$ and $30 \%(6 / 20)$ respectively. None of these rates differed significantly, and they compared with a rate of $23 \%(6 / 26)$ in a control group of patients with unexplained infertility. Those patients in whom the disease was eliminated did not return to normal fertility, though all other causes of infertility were excluded.

This study failed to show any impact of treatment or the absence or presence of asymptomatic endometriosis on future fertility compared with patients with unexplained infertility. The findings therefore question any causal role of the disease in infertility.
\end{abstract}

\section{Introduction}

In fertile women the prevalence of endometriosis found incidentally at laparoscopy is reported as between $2 \cdot 5 \%$ and $5 \cdot 0 \% .^{12}$ In infertile women the prevalence is variously reported as between $20 \%$ and $50 \% .^{3-5}$ Hence there is a relation between endometriosis and infertility, and in the belief that this is causal many studies have reported a high pregnancy rate after either surgical or medical

University Department of Obstetrics and Gynaecology, The Jessop Hospital for Women, Sheffield S3 7RE

ERIC J THOMAS, MRCOG, lecturer

IAN D COOKE, FRCOG, professor

Correspondence to: Dr Thomas. treatment. . $^{-8}$ These and other studies may be criticised, however, for being either retrospective or uncontrolled, for not using random allocation, or for not employing cumulative conception rates for comparison. The only prospective controlled randomised study of any treatment of endometriosis in infertile women found no difference in pregnancy rates between those prescribed danazol and those untreated. ${ }^{9}$ The authors later extended their study and still failed to show any benefit of treatment. ${ }^{10}$ Laparoscopy was not performed after treatment, so that it was not possible to tell whether the elimination of endometriosis benefited fertility in comparison with patients with residual disease.

In view of the methodological problems in other studies we decided to address the question of whether endometriosis is causal in infertility by instigating a randomised double blind placebo controlled trial of gestrinone (13 $\beta$-ethyl-17 $\alpha$-ethinyl-17hydroxygona-4,9,11-trien-3-one; Roussel-UCLAF, Paris) in the treatment of this problem. We have already reported the beneficial effect of this drug on the endometriosis itself, " and this study describes the impact of treatment on future fertility.

\section{Patients and methods}

The study was a prospective double blind randomised controlled trial of the effect of gestrinone on future fertility in infertile women with asymptomatic endometriosis. Forty patients were recruited after a laparoscopy for infertility at which endometriosis had been diagnosed visually and scored using the American Fertility Society system. ${ }^{12}$ Only patients in whom the disease did not impede collection of the oocyte by the tubal fimbria were included. They were randomly allocated to receive oral placebo or gestrinone $2.5 \mathrm{mg}$ twice weekly and had a repeat laparoscopy after 24 weeks' treatment. All patients were then followed up for one year to see if they conceived.

All patients had complained of at least 12 months of primary or secondary infertility. Before the initial laparoscopy they were diagnosed as having unexplained infertility on the basis of the following: $(a)$ verbal verification of regular sexual intercourse; $(b)$ a menstrual cycle of $23-35$ days $^{13}$ with a biphasic body temperature; $(c)$ normal thyroid function and full blood count and a plasma prolactin concentration of less than $760 \mathrm{mIU} / 1^{14} ;(d)$ a normal hysterosalpingogram; and $(e)$ normal semen, as defined by the World Health Organisation. ${ }^{15}$

Patients gave written informed consent and the study was approved by the local ethical committee. 
Statistical method-Fertility was described using cumulative conception rates at six and 12 months. ${ }^{16}$ These were calculated in those patients prescribed gestrinone and those prescribed placebo. These same patients were then divided into those with elimination of visible endometriosis and those with residual disease at the second laparoscopy and the rates recalculated. Finally, the rate was calculated in other patients with unexplained infertility. Statistical comparison of rates was by $\chi^{2}$ analysis. This analysis would be able to determine if there was a large impact on future fertility from any of the variables, but we appreciated beforehand that the number of patients in each group would introduce a large false negative error. Therefore, the patients were so selected as to allow a second analysis to be performed. By excluding all other causes of infertility we hypothesised that if asymptomatic endometriosis was the direct cause of the problem then its eradication would lead to normal fertility. If the endometriosis was irrelevant to the infertility then after its eradication the women would continue as if they had unexplained infertility. The 12 month cumulative conception rate in normal women is $88 \%,{ }^{17}$ whereas in those with unexplained infertility it is between $10 \%$ and $18 \%{ }^{18}$ This difference is so large that fewer than 10 patients would be needed in each group to show it to be statistically significant. ${ }^{19}$

\section{Results}

Ninety eight infertile women who fulfilled the initial criteria had a diagnostic laparoscopy. Of these, 51 were diagnosed as having endometriosis, 15 as having tubal or ovarian adhesions not associated with endometriosis, and in the remaining 32 patients there was no demonstrable abnormality. In this last group results of all investigations, including laparoscopy, had been negative and the patients were considered to have unexplained infertility; these patients therefore served as controls. Only 26 were included in the final analysis, however, as two patients stopped trying to conceive and four were prescribed ovulation induction treatment empirically. Of the 51 patients diagnosed as having endometriosis, three had adhesions that limited tubal or ovarian mobility and eight refused to enter the study. The median score for endometriosis was 2 (range 1-8). In the revised American Fertility Society system a score of less than 6 constitutes minimal disease and a score of 6-15 mild disease. Severe disease is denoted by scores in excess of 40 .

Of the $\mathbf{4 0}$ patients who were recruited, three withdrew. In addition, one patient withdrew after three months of treatment but had a second laparoscopy and one completed the treatment but did not have a second laparoscopy because of a fractured tibia and fibula. We decided to include these two patients, and the treatment groups therefore comprised 20 patients

TABLE I-Comparison of medians and ranges for age, duration of infertility, and Quetelet's index of weight over height $\left(\mathrm{kg} /\left(\mathrm{m}^{2}\right)\right)$ and proportions of parous women among those prescribed gestrinome, those prescribed placebo, those with elimination of endometriosis, those with residual disease, and those with unexplained infertility

\begin{tabular}{lcccc}
\hline & $\begin{array}{c}\text { Age } \\
\text { (years) }\end{array}$ & $\begin{array}{c}\text { No(\%) } \\
\text { parous }\end{array}$ & $\begin{array}{c}\text { Duration of } \\
\text { infertility } \\
\text { (months) }\end{array}$ & $\begin{array}{c}\text { Quetelet } \\
\text { index }\end{array}$ \\
\hline Placebo $(\mathbf{n}=17)$ & $27(21-34)$ & $6(35)$ & $36(18-60)$ & $21(18-28)$ \\
Gestrinone $(\mathbf{n}=20)$ & $28(22-35)$ & $7(35)$ & $38(17-66)$ & $22(18-26)$ \\
Endometriosis eliminated $(\mathbf{n}=16)$ & $28(22-35)$ & $4(25)$ & $38(17-66)$ & $21(18-26)$ \\
Residual endometriosis $(\mathbf{n}=20)$ & $28(21-34)$ & $9(45)$ & $37(18-60)$ & $22(19-28)$ \\
Unexplained infertility $(\mathbf{n}=26)$ & $28(21-36)$ & $\mathbf{8}(31)$ & $30(18-72)$ & $23(16-32)$ \\
\hline
\end{tabular}

TABLE II-Percentage cumulative conception rates at six and 12 months in normal women, those with elimination of endometriosis, those with residual disease, those prescribed gestrinone, those prescribed placebo, and those with unexplained infertility

\begin{tabular}{|c|c|c|c|c|}
\hline & \multicolumn{2}{|c|}{6 Months } & \multicolumn{2}{|c|}{12 Months } \\
\hline & $\begin{array}{l}\text { Cumulative } \\
\text { conception } \\
\text { rate }\end{array}$ & $\begin{array}{c}95 \% \\
\text { Confidence } \\
\text { interval }\end{array}$ & $\begin{array}{l}\text { Cumulative } \\
\text { conception } \\
\text { rate }\end{array}$ & $\begin{array}{l}95 \% \\
\text { Confidence } \\
\text { interval }\end{array}$ \\
\hline $\begin{array}{l}\text { Endometriosis eliminated }(n=16) \\
\text { Residual endometriosis }(n=20)\end{array}$ & $\begin{array}{l}13(n=2) \\
25(n=5)\end{array}$ & $\begin{array}{l}0 \text { to } 30 \\
6 \text { to } 44\end{array}$ & $\begin{array}{l}25(n=4) \\
30(n=6)\end{array}$ & $\begin{array}{l}3 \text { to } 47 \\
5 \text { to } 55\end{array}$ \\
\hline $\begin{array}{l}\text { Prescribed gestrinone }(n=20) \\
\text { Prescribed placebo }(n=17)\end{array}$ & $\begin{array}{l}20(n=4) \\
18(n=3)\end{array}$ & $\begin{array}{l}2 \text { to } 38 \\
0 \text { to } 37\end{array}$ & $\begin{array}{l}25(n=5) \\
24(n=4)\end{array}$ & $\begin{array}{l}6 \text { to } 44 \\
2 \text { to } 45\end{array}$ \\
\hline $\begin{array}{l}\text { Unexplained infertility }(n=26) \\
\text { Normal women }(n=611) \\
\text { (after Tietze }{ }^{17} \text { ) }\end{array}$ & $\begin{array}{l}8(n=2) \\
77\end{array}$ & 0 to 19 & $\begin{array}{l}23(n=6) \\
88\end{array}$ & 6 to 40 \\
\hline
\end{tabular}

given gestrinone and 17 given placebo. Of the 36 patients who had the second laparoscopy, 16 had complete elimination of visual endometriosis and in 20 there was residual disease. Of the sixteen with complete elimination, four had been prescribed placebo and 12 gestrinone. In the patients prescribed gestrinone menstruation returned within six weeks after stopping the drug.

Table I gives the age, parity, duration of infertility, and Quetelet's index of weight over height $\left(\mathrm{kg} /\left(\mathrm{m}^{2}\right)\right)$ in each of the five groups. These factors may influence future fertility and were comparable in all groups. Table II compares the cumulative conception rates at six and 12 months in the five groups. There was no difference between the placebo and gestrinone treated groups or between those with elimination of endometriosis and those with residual disease. Furthermore, in patients with elimination of endometriosis the cumulative conception rate at both six and 12 months was significantly less than that in normal women $\left(\chi^{2}=27\right.$ and $\left.25 ; p<0.001\right)$. The rates in all groups in the randomised trial were comparable with that in the patients with unexplained infertility.

\section{Discussion}

This is the first study to combine randomised placebo control with post-treatment laparoscopy and so allow assessment of not only the impact of treatment of endometriosis on future fertility but also whether complete elimination of the disease is of any benefit. We were not able to show that either treatment or elimination of the disease affected future fertility, which questions a causal role of asymptomatic endometriosis in infertility. Furthermore, patients with complete elimination of the disease did not return to normal fertility, which hypothetically should have occurred had endometriosis been a direct cause of their problem.

We accept that because of the small numbers of patients in this study we cannot disprove a partial impact of endometriosis on future fertility. Logistic problems would make it difficult for a single centre to mount a large enough study, as it would require roughly 180 patients to detect a $20 \%$ increase in a 12 month cumulative conception rate as a result of treatment with an acceptable false negative and false positive error. ${ }^{19}$ As we have shown that endometriosis deteriorates in a significant proportion of patients if left untreated" it would be difficult to mount such a study.

Abnormalities in prostaglandins, ${ }^{2021}$ peritoneal macrophages, ${ }^{22}{ }^{23}$ immune phenomena, ${ }^{24}{ }^{25}$ the oocyte, ${ }^{26}$ and endocrine factor ${ }^{27-29}$ have all been implicated in mediating infertility in mild endometriosis. In all studies the endometriosis was diagnosed visually and the control groups were infertile patients with no visible disease. As we could not show any impact of the presence or absence of visible endometriosis on future fertility the relevance of these factors is debatable. They may be either causal in the endometriosis itself or simply epiphenomenal to the disease. Until further evidence is presented about the pathogenesis of the disease these problems will remain unresolved.

Conclusions concerning the irrelevance of endometriosis to future fertility are strongly supported by the comparability of cumulative conception rates with that in the group of patients with unexplained infertility. The rate in this group was comparable with that reported in a retrospective study from this department. ${ }^{18}$ It was, however, much lower than that reported elsewhere. ${ }^{30}{ }^{31}$ In those studies such factors as mild endometriosis and periovarian and peritubal adhesions did not exclude a diagnosis of unexplained infertility and normal appearances on laparoscopy were not obligatory. Hence the studies are not comparable, and as our definition was more rigorous the lower rate is more appropriate to the diagnosis.

In summary, we have not shown that mild endometriosis is directly causal in infertility; it may be irrelevant to the diagnosis. We have already reported that the disease deteriorates if not treated, and therefore medical or surgical intervention is important even in infertile patients with asymptomatic disease. Clinicians, however, should not assume that they have solved the infertility by treating the endometriosis and should consider these patients to have unexplained infertility. After their course of treatment it would be appropriate to recommend them for either further investigations or in vitro fertilisation as further treatment for their problem. 


\section{References}

1 Drake TS, Grunert GM. The unsuspected pelvic factor in the infertility investigation. Fertil Sueril $1980 ; 34 \cdot 27-32$

2 Strathy JH, Molgaard CA, Coulam CB, Melton LJ. Endometriosis and infertility: a laparoscopic study of endometriosis among fertile and infertile women. Fertil Steril 1982;38:667-72.

3 Peterson EP, Behrman SJ. Laparoscopy of the infertile patient. Obstet Gynecol 1970;36:363-7.

4 Goldenberg RL, Magendantz HG. Laparoscopy and the infertility evaluation. Obsta Gymecol 1976;47:410-4.

5 Hasson HM. Incidence of endometriosis in diagnostic laparoscopy. I Reprod Med 1976;16:135-8.

Schenken RS, Malinak LR. Conservative surgery versus expectant management for the infertile patient with mild endometriosis. Fertil Steril 1982;37:183-6.

7 Dmowski WP, Cohen MR. Antigonadotrophin (danazol) in the treatment of endometriosis. Evaluation of post treatment fertility and three year follow up data. Am $\mathcal{f}$ Obstet Gymecol 1978;130:41-7.

8 Buttram VC, Reiter RC, Ward S. Treatment of endometriosis with danazol: report of a 6 year prospective study. Fertil Steril 1985;43:353-60.

9 Seibel MM, Berger MJ, Weinstein FG, Taymor ML. The effectiveness of danazol on subsequent fertility in minimal endometriosis. Fertil Steril 1982;38:534-7.

10 Bayer $S$, Seibel $M$, Seffan $D$, Berger $M$, Taymor $M$. The efficacy of danazol treatment in an infertile population with mild endometriosis. Fertil Steril 1986;46(program suppl): 17.

11 Thomas EJ, Cooke ID. Impact of gestrinone on the course of asymptomatic endometriosis. BrMed f 1987;294:272-4.

12 American Fertility Society. Revised American Fertility Society classification of endometriosis. Fertil Steril 1985;43:351-2.

13 Lenton EA, Landgren B-M, Sexton L. Normal variation in the length of the luteal phase of the menstrual cycle: identification of the short luteal phase. Br $\mathcal{Y}$ Obstet Gynaecol 1984;91:685-9.

14 Lenton EA, Sulaiman R, Sobowale O, Cooke ID. The human menstrual cycle: plasma concentrations of prolactin, LH, FSH, oestradiol and progesterone in conceiving and nonconceiving women. I Reprod F ertil 1982;65:131-9.

15 Belsey MA, Eliasson R, Gallegos AJ, Moghissi K, Paulsen C, Prasad M. Laboratory manual for the examination of human semen and semen-cervical mucus interaction. Singapore: Press Concern, 1980.

16 Cooke ID, Sulaiman RA, Lenton EA, Parsons RJ. Fertility and infertility statistics: their importance and application. Clin Obstet Gymecol 1981;8:531-48.
17 Tietze C. Fertility after discontinuation of intrauterine and oral contraception. Int $\mathcal{J}$ Fertil 1968;13:385-9.

18 Lenton EA, Weston GA, Cooke ID. Long term follow-up of the apparently normal couple with a complaint of infertility. Fertil Steril 1977;28:913-9.

19 Pocock SJ. Statistical methods for determining trial size in clinical trials. Clinical trials: a practical approach. Chichester: John Wiley \& Sons, 1983:123-33.

20 Sondheimer SJ, Flickinger G. Prostaglandin $F_{2}$ in the peritoneal fluid of patients with endometriosis. Int f F erril 1982;27:73-5.

21 Badawy SZA, Cuenca V, Marshall L, Munchback R, Rinas AC, Coble DA. Cellular components in peritoneal fluid in infertile patients with and without endometriosis. Fertil Steril 1984;42: 7048 .

22 Muscato JJ, Haney AF, Weinberg JB. Sperm phagocytosis by human peritoneal macrophages: a possible cause for infertility in endometriosis. Am f Obstet Gymecol 1982;144:503-10.

23 Halme J, Becker S, Hammond MG, Ray MHG, Ray S. Increased activation of pelvic macrophages in infertile women with mild endometriosis. Am J Obstet Gynecol 1983;145:333-7.

24 Mathur S, Peress MR, Wiliamson HO, a al. Autoimmunity to endometrium and ovary in endometriosis. Clin Exp Imemunol 1982;50:259-66.

25 Steele RW, Dmowski WP, Marmer DJ. Immunologic aspects of human endometriosis. Am $\mathcal{J}$ Reprod Imemunol 1984;6:33-6.

26 Wardle PG, McLaughlin EA, McDermott A, Mitchell JD, Ray BD, Hull MGR. Endometriosis and ovulatory disorder: reduced fertilization in vitro compared with tubal and unexplained infertility. Lancer 1985;ii:236-9.

27 Soules MR, Malinak LR, Bury R, Poindexter A. Endometriosis and anovulation: a coexisting problem in the infertile female. Am $\mathcal{J}$ Obstet Gymecol 1976;125:412-5.

28 Diobsti WP, Cohen MR, Wilhelm JL Endometiosis and ovulatory failure: does it occur? Should ovulatory stimulating agents be used? In: Greenblatt RB, ed. Recent advances in
endometriosis. Amsterdam: Excerpta Medica, 1976:129-36. (Intemational Congress Series No 368.)

29 Koninckx PR, Brosens IA. The luteinised unruptured follicle syndrome. Obstet Gynecol Annu 1982;11:175-86.

30 Hull MGR, Savage PE, Bromham DR. Anovulatory and ovulatory infertility: results with simplified management. BrMed F 1982;284:1681-5.

31 Hull MGR, Glazener CMA, Kelly NJ, es al. Population study of courses, treatment, and outcome of infertility. Br Med J 1985;291:1693-7.

(Accepted 9 March 1987)

\title{
Effects of intradermal bradykinin after inhibition of angiotensin converting enzyme
}

\author{
R E FERNER, JUDY M SIMPSON, M D RAWLINS
}

\begin{abstract}
Inhibitors of angiotensin converting enzyme may cause angiooedema. To see if this might be due to potentiation of the tissue effects of bradykinin the thickness of weals raised by intradermal injection of saline or 1,3 , or $10 \mu \mathrm{g}$ bradykinin was measured before and three times after single doses of captopril, enalapril, or placebo. The mean thickness increased with increasing doses of bradykinin. It did not change with time after the administration of placebo or captopril but increased from $0.61 \mathrm{~mm}$ before enalapril to $1.12 \mathrm{~mm}$ two and a half hours and $1.06 \mathrm{~mm}$ five hours after enalapril was given. Five subjects flushed when given bradykinin after captopril and four after enalapril, but none flushed when given bradykinin after placebo.

It is concluded that angiotensin converting enzyme inhibitors potentiate the effects of intradermal bradykinin in vivo and that this may partially explain why they cause angio-oedema in susceptible patients.
\end{abstract}

\footnotetext{
Wolfson Unit of Clinical Pharmacology and Department of Medical Statistics,

University of Newcastle upon Tyne, Newcastle upon Tyne NE1 7RU

R E FERNER, MSC, MRCP, senior registrar

JUDY M SIMPSON, PHD, lecturer

M D RAWLINS, MD, FRCP, professor of clinical pharmacology

Correspondence to: Dr Ferner.
}

\section{Introduction}

Angio-oedema is an occasional but potentially fatal adverse reaction to angiotensin converting enzyme inhibitors. It occurs with both captopril and enalapril,,$^{2}$ and often develops within 48 hours after treatment is started. ${ }^{3}$ Bradykinin, a nonapeptide that causes vasodilatation and increased vascular permeability, has been implicated in the pathogenesis of the angio-oedema ${ }^{4}$ as it is inactivated by two distinct proteases, one of which (kininase II) is identical with angiotensin converting enzyme. ${ }^{5}$ Treatment with captopril increases the effect of intra-arterial bradykinin on forearm blood flow. ${ }^{6}$ Blood concentrations of bradykinin do not seem to be increased during treatment with angiotensin converting enzyme inhibitors. ${ }^{7}$ Thus the development of angio-oedema in patients receiving angiotensin converting enzyme inhibitors may be due to the reduced destruction of bradykinin formed locally in subcutaneous tissues. To investigate this possiblity we studied the effects of angiotensin converting enzyme inhibitors on dermal weals induced by bradykinin.

\section{Subjects and methods}

We studied six healthy subjects aged 22-45 with normal full blood count, urea and electrolyte concentrations, and results of biochemical tests of liver function. None had any history of cardiovascular disease, hypertension, or drug allergy or was taking any medicine. All gave written informed consent to the study, which was approved by the university ethics committee. The subjects fasted from midnight before each study, and each received on separate occasions oral captopril $25 \mathrm{mg}$, enalapril $10 \mathrm{mg}$, or lactose placebo in identical capsules according to a randomised double blind trial design.

Solutions of bradykinin (Sigma Chemical Co Ltd, Poole, Dorset) in 0.9\% 